\title{
Enhancing the Performance of Surface-based Biosensors by AC Electrokinetic Effects - a Review
}

\author{
Protiva Rani Roy, Matthew R. Tomkins and Aristides Docoslis \\ Department of Chemical Engineering, Queen's University, Kingston, ON
}

Canada

\section{Introduction}

Miniaturized surface based biosensors are a cost effective and portable means for the sensing of biologically active compounds. With advents in micro- and nanotechnology, the design of surface based biosensors can be adapted for various detection goals and for integration with multiple detection techniques. In particular, the issue of pathogen detection is an important challenge with applications in defence, health care, food safety, diagnostics and clinical research. The research of micro-fluidic analytical systems, such as surface based biosensors or "lab-on-a-chip" designs, have gained increasing popularity, not only due to the enhancement of the analytical performance, but also due to their reduced size, decreased consumption of reagents and the ability to integrate multiple technologies within a single device. Although conventional pathogen detection methods are well established, they are greatly restricted by the assay time. For pathogens that typically occur at low concentrations, the mass transfer required for detection is diffusion limited and incubation is often needed in order to enhance the concentration of the target analyte. AC electrokinetic effects provide a means for biosensors to detect pathogens quickly and at lower concentrations, thus overcoming these bottlenecks.

\section{Overview of $A C$ electrokinetic phenomena}

AC electrokinetics deals with the movement of a particle and/or the fluid by means of an AC electric field and has received considerable attention for improving the capture of analytes. An example of an AC electrokinetic force is dielectrophoresis (DEP) where a nonuniform electric field acts on an uncharged particle. When acting on a fluid, AC electrokinetic forces can induce AC electroosmosis and AC electrothermal effects. These forces can create non-uniform streamlines to convex and $\operatorname{mix}(\mathrm{Li}, 2004)$, or even to separate a mixture of particle sizes (Green \& Morgan, 1998). Most bioparticles, such as cells and viruses, behave as dielectrically polarized particles in the presence of an external field. Using AC electric fields for particle manipulation offers several advantages, such as allowing operation at low voltages, which is important for portable devices and minimizing electrolysis and chemical reactions. The following will provide a brief overview of AC electrokinetic forces with applications for use in biosensors, as comprehensive reviews of AC electrokinetic forces in general are available elsewhere (Ramos et al., 1998). 
DEP is a force acting on the induced dipole of a polarizable particle in a suspending fluid in the presence of a non-uniform electric field (Pohl, 1951). It was first defined by Pohl in 1951, and was used to remove suspended particles from a polymer solution. Pethig \& Markx (1997) provides a review of applied DEP in the field of biotechnology. In brief, if a particle, such as a bacterium or virus, is more polarizable than the surrounding medium, the particle undergoes positive DEP (pDEP) and tends towards areas of high electric field strength (Fig 1a-Left). If a particle is less polarizable than the surrounding medium, it undergoes negative $\mathrm{DEP}(\mathrm{nDEP})$ and tends towards areas of electric field minima (Fig 1a-Right).

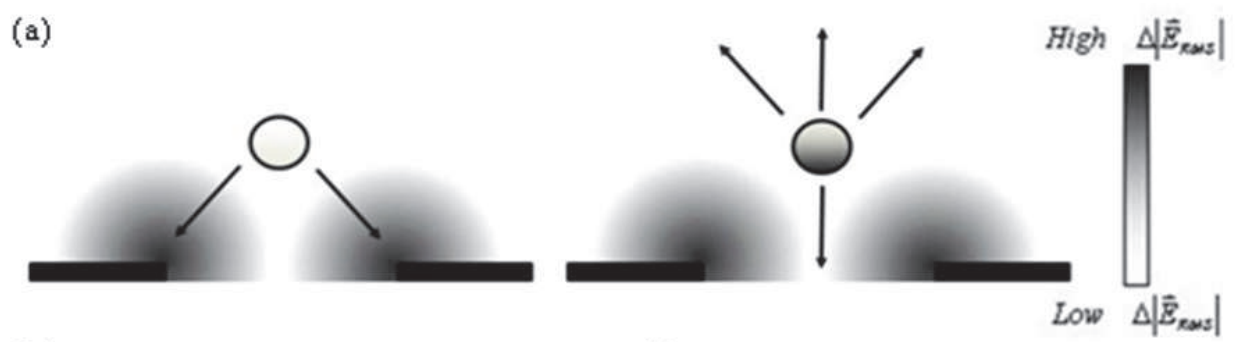

(b)
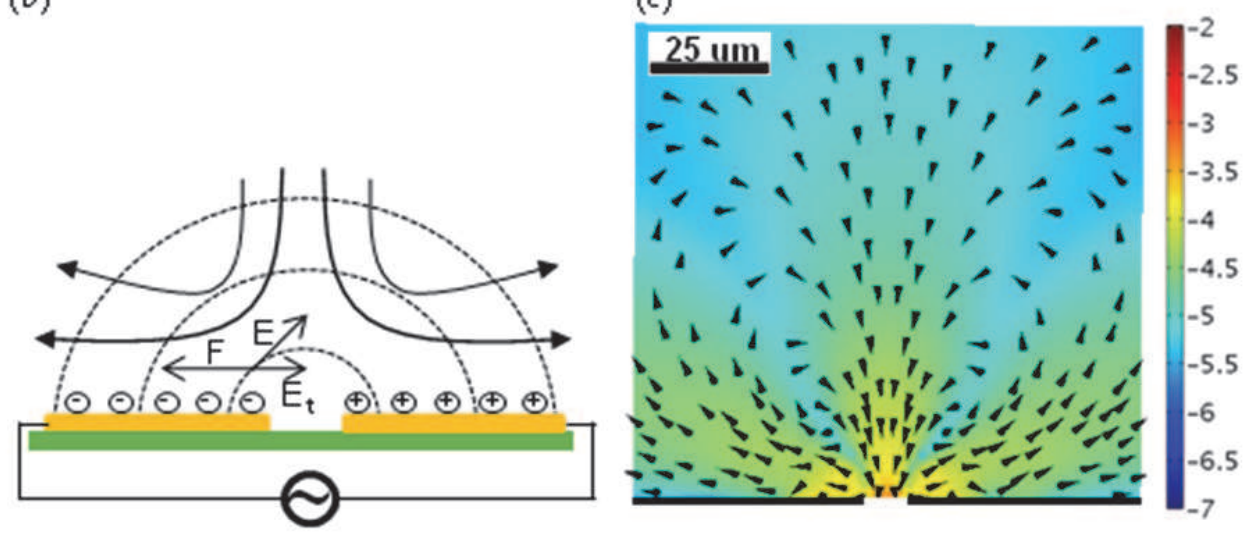

Fig. 1. AC electrokinetic effects generated by a pair of electrodes (horizontal gold or black bars) located on the surface of a non-conductive substrate. a) A schematic representation of a particle undergoing pDEP (left) and nDEP (right) in a non-uniform electric field. $b$ ) The reported mechanism for AC-electroosmosis where the arrows indicate fluid flow driven down towards the electrode gap and out along the surface of the electrode due to the force of the tangential component of the electric field on the ions in solution. Adapted from Morgan \& Green (2003). c) Circulation pattern of fluid near the electrode edge created by electrothermal effects where the arrows indicate the net force on a suspended particle with an $r_{p}$ of $200 \mathrm{~nm}$. The colour intensity indicates the magnitude of the fluid velocity with an scale bar in $\log _{10} \mathrm{~m} / \mathrm{s}$. The circulation zones appear to be similar to a microfluidic system subjected to AC electroosmotic flow. (Tomkins et al., 2008).

The time averaged dielectrophoretic force for a spherical particle in an electric field with a constant phase is presented in equation 1. 


$$
<F_{D E P}>=2 \pi r_{p}^{3} \operatorname{Re}\left[\frac{\varepsilon_{p}^{*}-\varepsilon_{m}^{*}}{\varepsilon_{p}^{*}+2 \varepsilon_{m}^{*}}\right] \nabla^{2}\left|E_{R M S}\right|^{2}
$$

The equation shows that the DEP force $(\mathrm{F})$ is a function of a particle's size $\left(\mathrm{r}_{\mathrm{P}}\right)$, both the particle and the medium's complex permittivities $\left(\varepsilon_{p}^{*} \& \varepsilon_{m}^{*}\right)$ as well as the gradient of the applied electric field (E). Since the force of DEP varies with particle size and the electric field gradient, it allows for the separation between different sized cells. Alternatively, by measuring the velocities of single cells as a function of distance and voltage, DEP can be used to characterize their electrical properties (Pohl \& Pethig, 1977; Burt et al., 1990; Humberto et al., 2008). However, the most attractive application of DEP is that it can be integrated within a biosensor with a pair of electrodes in order to amplify a pathogen's concentration at a sensor surface. The use of either $\mathrm{pDEP}$ or nDEP causes the deterministic motion of particles towards the desired location; yet, it is a short range force. The same electric field for applied DEP can have an effect on the medium as well by causing fluid flows and thereby overcoming limitations due to diffusion by enhancing the movement of particles from the bulk to the local area of the sensor (Sigurdson et al., 2005).

AC electroosmosis and AC electrothermal effects produce similar flow patterns in some cases, but they are of different origin. AC electroosmotic flow is typically produced from the interaction of the nonuniform electric field and the diffuse electrical double layer formed by the polarization of the electrode by the counter ions in an electrolyte solution (Fig 1b). The tangential component of the electric field $\left(\mathrm{E}_{\mathrm{t}}\right)$ at the electrode surface applies a force $(\mathrm{F})$ on the ions present, pushing them out across the surface of the electrode and thus dragging fluid down into the center of the gap. The time averaged fluid velocity due to AC electroosmosis is presented in equation 2.

$$
<u_{x}>=\frac{1}{2} \operatorname{Re}\left[\frac{\sigma_{q o} E_{t}^{*}}{\eta \kappa}\right]
$$

AC electroosmosis is a function of the surface charge density $\left(\sigma_{\mathrm{qo}}\right)$, fluid viscosity $(\eta)$ and the reciprocal debye length $(\mathrm{k})$. At low frequencies, the majority of the potential drop occurs at the double layer near the electrodes. Therefore, the remaining voltage drop across the electrodes is small in comparison and since the tangential component of the electric field must be continuous the resulting velocity due to AC electroosmosis is negligible. At high frequencies, the potential across the double layer is very small and results in virtually no induced charge, again causing negligible $\mathrm{AC}$ electroosmosis effects. $\mathrm{AC}$ electroosmosis dominates at frequencies between 100 and 100,000 Hz while above 100,000 Hz, AC electrothermal flow is predominant. AC electrothermal flow arises by uneven Joule heating of the fluid, which gives rise to nonuniformities in conductivity and permittivity. These nonuniformities interact with the electric field to generate flow, often in circulating patterns (Fig. 1c) (Feng et al., 2007). The time averaged body force on the medium responsible for the generation of AC electrothermal fluid flow for a constant phase electric field is presented in equation 3.

$$
<\vec{f}_{e}>=\frac{1}{2} \frac{\varepsilon_{m}(\alpha-\beta)}{\sigma_{m}^{2}+\left(\omega \tau_{C R}\right)^{2}}(\nabla T \cdot \vec{E}) \vec{E}-\frac{1}{4} \varepsilon_{m} \alpha|\vec{E}|^{2} \nabla T
$$


AC electrothermal fluid flow is a function of: $\alpha$ and $\beta$ the effects of temperature on the gradients of permittivity and conductivity respectively; and $\tau_{C R}$, the charge relaxation time of the medium defined as the ratio of a medium's permittivity to its conductivity. The first term on the right hand side of equation 3 is the Coloumbic contribution while the second term is the dielectric contribution to the total force. The Columbic term dominates at frequencies below the charge relaxation time.

Due to the range of effective frequencies, voltages and ease of application, a number of researchers have proposed techniques to enhance the activity of microfluidic sensors by using AC electrohydrodynamic flows (Sigurdson et al., 2005; Hoettges et al., 2003; Gagnon \& Chang, 2005; Wu et al., 2005a; Sauli et al., 2005; Hou et al., 2007; Wu et al., 2005b). This chapter will review the use of AC electrokinetics to develop biosensors for pathogens as well as the different detection techniques employed.

\section{Manipulation of bioparticles by AC Electrokinetics}

Before surface based biosensors can identify a target bioparticle, that bioparticle must first move from the bulk sample towards the sensing element and then become captured or detected. As demonstrated in the previous section, AC electrokinetics effects can be used to affect both the movement of bioparticles from the bulk. Through AC electroosmosis or AC electrothermal flows bioparticles are continuously brought towards the sensing element overcoming any diffusion limitations. With DEP, the bioparticles are retained in proximity to the sensing element allowing for more time for capturing or detection to take place. Without these driving forces, biosensors can suffer from poor detection limits because of the low number distribution of molecules in the detection region and limited physical sensitivity of the transducer. The literature presented will demonstrate how AC electrokinetics has been employed to manipulate cells, viruses and DNA for the performance enhancement of surface based biosensors.

\subsection{Biological cells}

Cells, including bacteria and yeast, represent the largest sized bioparticles in the category of pathogens and are generally the most easily influenced by AC electrokinetic effects. One of the first reports dealing with the manipulation of cells was presented by Dimitrov \& Zhelev (1987) where the manipulation, dielectrophoretic mobility, and dielectrophoretic coefficients of individual cells were examined under different conditions. The capability to move cells based on their dielectric properties allowed for DEP to be useful in the separation of mammalian cells (Gascoyne et al., 1992), viable and nonviable cells (Markx et al., 1994; Oblak et al., 2007; Li \& Bashir, 2002; Talary et al., 1996; Jen \& Chen, 2009), microorganisms (Markx et al., 1995) and human breast cancer cells from blood cells (Becker et al., 1995). This cell sorting allows for the screening of cells prior to exposure to a biosensor's surface thus providing a means of rapid sample sorting.

Depending on the sensing location and the dielectric properties of the pathogen of interest, the electrode design can be important consideration. Interdigitated castellated microelectrodes have been widely used for cell manipulation and separation (Betts, 1995; Oblak et al., 20007; Pethig et al., 1992; Pethig, 1996) as this design allows for the differential focusing and collection of cells at distinct electrodes areas under the influence of both positive and negative dielectrophoretic forces (Gascoyne et al., 1992). In 1991 the first 
polynomial electrode design was reported to produce a well defined non-uniform electric field for the study and application of nDEP (Huang \& Pethig, 1991). An example of this is presented in Fig. 2 where E. coli and M. Lysodeikticus are separated using a polynomial electrode setup. Recently, a simple and novel curved electrode design has been used for the separation of airborne microbes from beads or dust that are present in airborne environmental samples, an important task prior to the real-time detection of airborne microbes (Sungmoon et al., 2009).

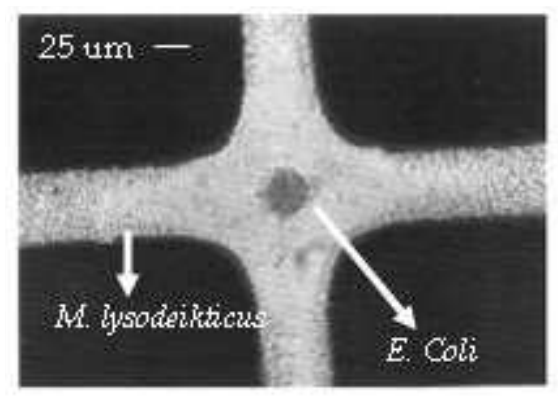

Fig. 2. Separation of E. coli (experiencing nDEP) and M. lysodeikticus (experiencing pDEP) in a polynomial electrode after application of a $4 \mathrm{~V}_{\mathrm{PP}}, 100 \mathrm{kHz}$ signal in a suspending medium of $280 \mathrm{mM}$ mannitol with a conductivity of $550 \mu \mathrm{S} \mathrm{cm}-1$ (Markx et al., 1994). Reused with permission.

In order for quantitative and qualitative studies to take place on a single cell or a small population of cells, the isolation and accurate positioning of the target must first be accomplished. Negative dielectrophoresis in particular has emerged as a powerful tool for this role. Under the influence of nDEP bioparticles are typically driven to regions away from the electrodes. The E. Coli in fig. 2 are collected in a nDEP "trap" or "cage" at the center because the electric field at that point is a localized minimum. This concept can be expanded to arrays of microelectrodes, thus enabling the precise placement and retention of multiple pathogenic samples (Frenea et al., 2003).

\subsection{Viruses}

Representing some of the smallest size pathogenic bioparticles, the manipulation of virus particles is made difficult due to the presence of Brownian motion. To overcome the random stochastic motion, the manipulation of submicron sized particles requires large deterministic forces. Since DEP scales with a particle's volume, an electric field gradient of sufficient magnitude must be generated to provide a powerful enough force and necessitates the use of electrodes separated by only a few microns (Mullery et al., 1996; Green \& Morgan, 1997). Reducing the dimensions of the electrodes in a biosensor will decrease the voltage required to produce a given electrical field strength and, as a result, reduce both the power dissipated in the system and the temperature increment (Castellanos et al., 2003). This is particularly beneficial for portable systems that run on low power.

A number of reports currently exist on the subject of AC electrokinetic manipulation of viruses (Park et al., 2007; Akin et al., 2004; Wu et al., 2005a; de la Rica et al., 2008; Müller et al., 1996; Schnelle et al., 1996). In many of these cases, successful virus collection results from 


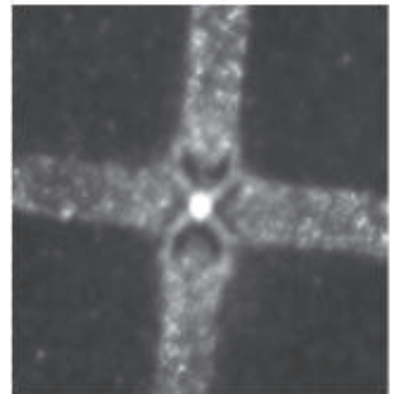

Fig. 3. Fluorescence image of nDEP collected vesicular stomatitis virus in TSE after fluorescent staining. The microelectrodes have a central gap measuring $2 \mu \mathrm{m}$ across.

a combination of DEP and electrohydrodynamic flows (Ramos et al., 1999). In 1998, Green \& Morgan reported the manipulation of a mammalian virus, herpes simplex virus type 1 , both by positive and negative DEP over a frequency range of $10 \mathrm{kHz}-20 \mathrm{MHz}$ using a polynomial microelectrode array with a gap of $2 \mu \mathrm{m}$. More recently, Docoslis et al. (2007) demonstrated the collection of vesicular stomatitis virus in buffered solutions of physiologically relevant conductivity using microelectrodes with a gap measuring $2 \mu \mathrm{m}$ across (Fig. 3).

\subsection{DNA}

DNA offers a potential tool for the selective detection of pathogens by means of detecting the presence or absence of genetic sequences found in specific pathogens. A DNA molecule consists of two strands of deoxyribonucleotides held together by hydrogen bonding and takes a random conformation in water. Under slightly basic conditions the DNA molecule becomes negatively charged and a counter ion cloud surrounds the molecule. This counter ion cloud can be displaced in the presence of an electric field, increasing the ionic polarizability of the molecule (Hölzel \& Bier, 2003). When an electrostatic field is applied, DNA polarizes, and every part of the DNA orients along the field lines, stretching it into an approximately straight shape. Due to the field non-uniformity, stretched DNA dielectrophoretically moves towards the electrode edge until one end comes into contact. On the basis of this behaviour many researchers have used AC electrokinetics to manipulate DNA (Walti et al., 2007; Lapizco-Encinas \& Palomares, 2007; Washizu et al., 1995 \& 2004; Dewarrat et al., 2002; Asbury et al., 2002; Washizu, 2005; Tuukkanen et al., 2006; Chou et al., 2002; Kawabata \& Washizu, 2001; Yamamoto et al., 2000; Wang et al., 2005). For example, a modified interdigitated microelectrode array, termed "zipper electrode" by the authors, has been reported to concentrate a wide range of nanoparticles of biological interest, such as the influenza virus and DNA (Hübner et al., 2007). Fig. 4 shows the fluorescence microscopy recorded for the trapping of stained $\lambda$-phage DNA in a floating electrode device. The figure shown here is recorded $10 \mathrm{sec}$ after the application of an electric field with a voltage of 200 $\mathrm{V}_{\mathrm{pp}}$ and a frequency of $30 \mathrm{~Hz}$.

The manipulation of DNA by AC electrokinetic effects has been applied in the biological field and reviewed recently by Washizu (2005). The versatility of DNA allows for it to be used as a sensing, or analytical device and AC electrokinetic effects play an important role in the manipulation of this biological tool. AC Electrokinetics has been used to perform molecular surgery for the reproducible cutting of DNA at any desired position along the 


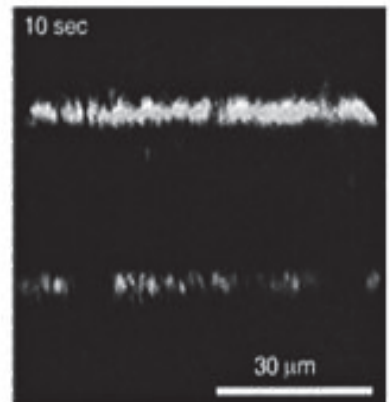

Fig. 4. Dielectrophoretic trapping of $\lambda$-phage DNA molecule when $30 \mathrm{~Hz}, 200 \mathrm{Vpp}$ signal was applied in a floating electrode device (Asbury et al., 2002). Reused with permission.

DNA molecule (Yamamoto et al., 2000). Gene mapping has also found AC electrokinetics useful as a means for manipulating DNA to bring it into contact with enzymes in order to search for binding locations, and thus mapping the gene (Kurosawa et al., 2000). Similarly manipulating and stretching DNA is useful for determining the order of the nucleotide bases for gene sequencing (Washizu et al., 2005), and for measuring molecular sizes by counting base pairs (Washizu \& Kurosawa, 1990). AC electrokinetically manipulated DNA can still undergo molecular interactions and has been used to achieve the selective binding of foreign single stranded DNA (Kawabata \& Washizu, 2001). As a detection and sensing tool, once the DNA is brought close enough to touch an electrode, if the electrode edge consists of an electrochemically active metal, such as aluminum, then the DNA becomes permanently anchored there (Washizu et al., 2004). Alternatively, the DNA can be trapped dielectrophoretically and it has been demonstrated by a number of researchers that trapped DNA can be used as a selective bioreceptor towards the development of pathogen biosensors (Gagnon et al., 2008; Lagally et al., 2005; Cheng et al., 1998a; Cheng et al., 1998b).

\section{Detection of AC-electrokinetically trapped particles}

Research over the last decade has shown that there is no shortage of analytical methods that can be successfully interfaced with AC electrokinetically enhanced sampling in a surfacebased biosensor. The most promising candidates include methods that rely on optical (absorbance measurement, Raman, confocal microscopy, fluorescent intensity, etc.), mass based (quartz crystal microbalance, surface acoustic wave, etc.), electrical, or electrochemical (potentiometric, amperometric, conductometric, coulometric, impedimetric) (Velusamy et al., 2010) detection. Optical and electrochemical sensors tend to be the most popular for pathogen analysis due to their selectivity and sensitivity. In general it is convenient to incorporate conventional optical or electrochemical devices with microfluidic detection systems. Successful implementation of these methods requires that the concentration amplification effect achieved by AC electrokinetics be combined with a selective target retention method. The latter can be accomplished with the immobilization of a targetspecific molecule, such as a strand of DNA, an antibody, a protein, or an enzyme, or a more complex biological system such as a membrane, cell or tissue (Velusamy et al., 2010). This type of molecular recognition ensures that the captured bioparticle will remain on the sensor surface even after the electric field is turned off. The sensitivity of a surface based biosensor 
is thus directly affected by the packing density of the sensing element bound to the surface. Methods for surface functionalization have included the use of thiol interactions (Park \& Kim, 1998; Radke \& Alocilja, 2005; Bhatia et al., 1989), avidin-biotin interactions (Costanzo et al., 2005), self-assembled monolayer coated electrodes (Wana et al., 2009), polymer coated electrodes (Livache et al., 1998) and size specific capillary flow trapping (Hamblin et al., 2010). A number of proof-of-principle studies have demonstrated that a combination of AC electrokinetics with a molecular recognition method can substantially improve the sensitivity of a biosensor (Yang, 2009; Yang et al., 2006; Yang et al., 2008). In principle, decorating the surface of the biosensor with antibodies allows for easy substitution when targeting a multitude of pathogens. The ability to replace specific bioreceptors on demand for the particular screening of a target pathogen gives this method high flexibility.

\subsection{Optical detection}

Optical based detections vary in their type and application. This section will focus on the most commonly used, namely: absorbance measurement, surface enhanced Raman scattering, and fluorescence.

\subsubsection{Absorbance based measurements}

An optical system was first described by Price et al., (1988) to detect dielectrophoretically trapped bacterial cells by monitoring the changes in light absorbance through the suspension as bacteria collected at an electrode array by pDEP. Later on, Pethig et al. (1992) reported a dual beam optical spectrometer with improved sensitivity for the detection of yeast cells collected by both nDEP and pDEP (Talary \& Pethig, 1994). The mechanism of pathogen detection by absorbance measurements based on dielectrophoretic immunocapture is illustrated in Fig. 5. The immuno-capture of the bacterial cells under DEP after 15 and $30 \mathrm{~min}$ of sampling was found to be $82 \%$ and $74 \%$ more efficient than that achieved without DEP. The immuno-captured bacterial cells were detected by sandwich format ELISA on the chips. The absorbance signals by DEP assisted immuno-capture were reported to be enhanced by $64.7-105.2 \%$ for samples containing $10^{3}-10^{6}$ cells $/ 20 \mu \mathrm{L}$ (Yang, 2009).

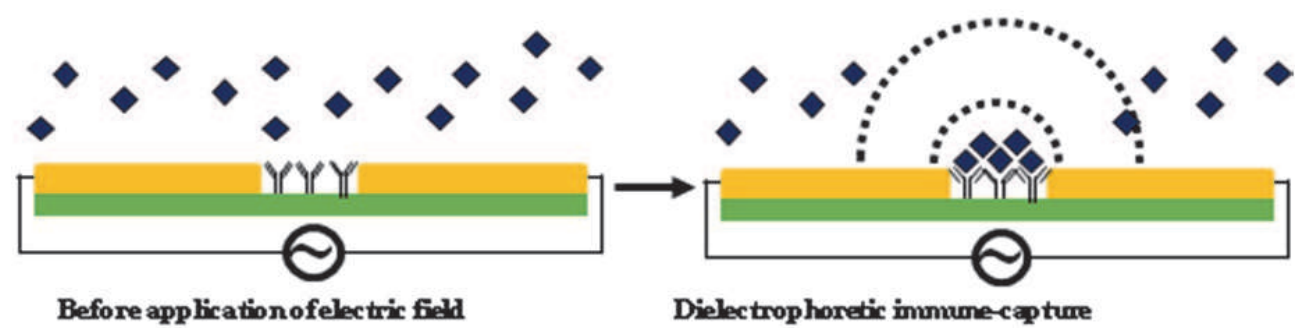

Fig. 5. Mechanism of nDEP immuno-capture: The area of collection (inter-electrode gap) is functionalized with a target-specific reactive component, an antibody in this case. Application of a spatially non-uniform electric field (dashed lines) causes nearby antigens to undergo $\mathrm{nDEP}$ and collect midway between the electrodes. Once collected, the immobilized antigens can be reacted with an optically active component. 


\subsubsection{Fluorescence-based detection}

Fluorescence is by far the most frequently used optical signalling method for the monitoring and detection of AC-electrokinetically trapped bioparticles due to its high level of sensitivity and low background noise (Hübner et al., 2007; Wong et al., 2004b; Cui et al., 2002; Yang et al., 2008). Using fluorescent imaging, Docoslis et al. (2007) detected captured virus (vesicular stomatitis virus) and later explored numerical simulations of the system to better understand the processes involved (Wood et al., 2007). The virus was captured from physiologically relevant ionic strength media $\left(880 \mathrm{mS} \mathrm{m}^{-1}\right)$ at low concentrations $\left(<10^{6} \mathrm{PFU}\right.$ $\mathrm{mL}^{-1}$ ). The numerical simulations revealed that with a quadrupolar microelectrode the capturing of the virus was achieved by both DEP for the short range capture and electrothermal fluid flow to overcome diffusion limitations. Others were also able to achieve virus capture at low ionic strengths $\left(1-100 \mathrm{mS} \mathrm{m}^{-1}\right)$ and higher particle concentrations $\left(>10^{6}\right.$ particles $\mathrm{mL}^{-1}$ ) (Hughes et al., 1998; Hughes et al., 2001; Pethig et al., 1992; Grom et al., 2006; Morgan \& Green, 1997). The dielectrophoretic capture and detection of a food borne pathogen, Listeria monocytogenes, was accomplished with the aid of the heat shock protein 60 (Hsp60) immobilized on a sensor's surface (Koo et al., 2009). Hsp60 is a receptor for the Listeria adhesion protein (LAP), a house keeping enzyme of Listeria monocytogenes during the intestinal phase infection. Both fluorescent microscopy and ELISA were used to detect the binding of target cells with the receptor. The enhancement of binding with the aid of DEP was found to be $60 \%$ higher than without. As discussed in section 3.3, single stranded DNA can be used as a receptor to detect the specific sequence of a pathogen's genetics. Lagally et al. (2005) described an integrated system where bacterial cells where electrokinetically concentrated from a continuous-flow and detected via DNA-rRNA hybridization. After pDEP trapping the bacterial cells, the cells were lysed by chaotropic salt and the released DNA was denatured by endonuclease. The E. Coli cells were detected by fluorescent detection via the sequence specific hybridization of an rRNA-directed optical molecular beacon with the denatured DNA. This integrated microsystem is capable of the sequence specific genetic detection of 25 cells within $30 \mathrm{~min}$. After hybridization, the percentage of the fluorescence was observed to increase with time and a linear relationship was found between the number of trapped cells and the percentage of maximum fluorescence. Others have reported the optical detection of cells (e.g., carcinoma cells, malarially-parasitized cells) where DEP was used to separate infected cells from healthy cells. Once lysed, the infected cells were identified with fluorescent probes on a bioelectronic chip (Gascoyne et al., 2004; Cheng et al., 1998a, 1998b).

\subsubsection{Raman spectroscopy}

Raman spectroscopy allows for analyte identification through the inspection of its "chemical fingerprint" on the basis of the vibrational, rotational and other low-frequency modes. Typically, for Raman detection, the signal provided by a low concentration surface based biosensor is not strong enough for detection. The use of surface enhanced Raman scattering (SERS) is often needed and can be achieved through the use of metal nanoparticles. The metal nanoparticles must be either chemically bonded to the bacteria or settle in the proximity of the bacteria in order to increase the scattering (Hou et al., 2007; Cheng et al., 2007). An on-chip detection of pathogens using surface enhanced raman spectroscopy (SERS) has been reported recently by Hou et al. (2007), where the Raman signals of the pathogens were enhanced by the presence of $\sim 80-100 \mathrm{~nm}$ silver 
nanoparticles. Combined with a discharge driven vortex for target concentration, SERS was successfully used in the detection of bioparticles at a concentration of $10^{4} \mathrm{CFU} / \mathrm{mL}$ in the presence of silver nanoparticles (Hou et al., 2007). A continuous flow system for bioparticle sorting was presented by Cheng et al. (2007) where, once sorted, the detection of the pathogen was accomplished via SERS. This integrated chip used DEP for a combination of filtering, focusing, sorting and trapping with a throughput of 500 particles/s (Cheng et al., 2007).

\subsection{Mass based detection}

Pathogenic particles with length scales on the order of nanometers can individually weight as little as tens of picograms. In order for mass based detection to succeed, either very sensitive detection methods or significant pathogen amplification is necessary. The following sections will examine how AC electrokinetics has been used to improve the mass based detection sensitivity and sampling for quartz crystal microbalances and cantilever based detection methods.

\subsubsection{Quartz crystal microbalance detection}

A quartz crystal microbalance (QCM) utilizes a piezoelectric quartz crystal that has a fundamental resonance frequency which changes in accordance to the amount of mass attached to the crystal surface. Fatoyinbo et al. (2007) developed for the first time an integrated system where yeast cells were concentrated on an electrode surface by DEP and then quantified by a QCM system. The steady-state response predicted from the frequency shift analysis of nanoparticle-loaded DEP-QCM has shown significant improvements in rates of particle detection. The work was done at a concentration of $10^{8}$ nano-spheres $/ \mathrm{mL}$ and detection was achieved five times faster than other QCM surface loading techniques described in the literature.

\subsubsection{Cantilever detection}

Similar in concept to the QCM, a cantilever acts as a free-standing platform whose resonant frequency decreases with the addition of mass. As more bioparticles become deposited on the surface, the shift becomes more pronounced. The combination of AC electrokinetics with a cantilever beam was recently achieved and allowed for the rapid collection of human cancer cells (Park et al., 2008). Using two conductive cantilevers situated across from one another over a well, Park et al. used pDEP to direct the human cancer cells onto the cantilever surface. Fig. 6 demonstrates the setup of a series of cantilevers where the change in resonant frequency is measured using a laser Doppler vibrometer. However, sensitivity remained an issue as culturing of up to 7 days was required in order for the cell mass to be detected. nDEP collection of E. Coli was achieved by Tomkins et al. (submitted, 2011) through the use of polynomial electrodes on a cantilever surface. By using a poly-L-lysine layer on the cantilever to act as a non-specific layer for the electrostatic retention of bacteria, a shift in frequency was detected after 30 minutes of collection from a concentration of $10^{8}$ particles / mL. In order to maximize the sensitivity of a cantilever beam, the most desirable location for collection is at the cantilever tip, furthest away from the anchor. However, Islam et al. (2007) successfully applied AC electroosmotic flow to drive polystyrene particles to a point near the anchor and detected a mass change after drying. 

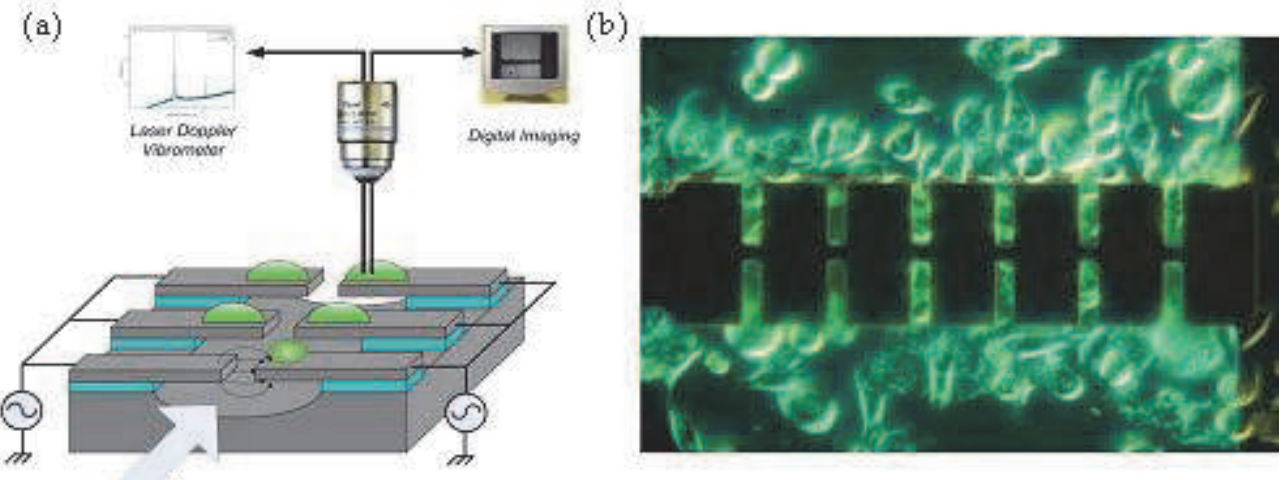

Fig. 6. (a) A schematic diagram of pairs of cantilevers. Each opposing cantilever acted as one half of an electrode pair when inducing pDEP. The arrow indicates the direction of flow. (b) A 'living' cantilever with human cervical cancer cells (Park et al., 2008). Reused with permission.

\subsection{Electrical or electrochemical detection}

When biosensors employ an electrical or electrochemical sensing element, many of the features needed for AC electrokinetics are already present. These methods are easier to interface with miniaturized devices than optical methods because they employ electrical signals and do not need an often bulky optical measuring system. Microelectrodes for applied AC electrokinetics can be easily added into a microfluidic channel using standard photolithographic techniques and their integration with an electrical diagnostic chip allows for the sharing of features or power sources. Moreover, some electrical sensing methods do not require a labelling step for sensing target pathogens which makes the on-chip enhanced sampling provided by AC electrokinetics an attractive asset. Electrical sensing methods can be separated into 4 subclasses depending on the type of signal being measured: amperometric (changes in current), conductometric (changes in conductance or resistance), impedimetric (changes in resistance to an AC current), and coulometric (changes in capacitance). This section will focus on recent electrical or electrochemical sensing methods that have used AC electrokinetics.

\subsubsection{Amperometric detection}

By measuring the change in current as pathogens pass between a pair of sensing electrodes, it is possible to detect single cells in solution. AC elecktrokinetics can be used to position or manipulate these single cells into the proper location to achieve sensing. Utilizing the Coulter-counter principle Pandey \& White (2004) used dielectrophoresis to detect a single cell (Chinese hamster ovary, $\mathrm{CHO}$ ) as it was driven to pass through a micro-aperture (10$25 \mu \mathrm{m}$ in diameter, comparable to the size of the cells being tested) in a silicon nitride membrane. Detection of a cell was achieved by recording the decrease in the ionic current caused from the passage of a single cell as it passed through the micro-aperture. Live bacteria were also detected amperometrically by first using pDEP to trap the bacteria and then using AC induced fluid flow to move the cells until they formed a bridge across micron-sized electrode gaps (Beck et al., 2005). The cells were first captured at the electrode edges by applying an electric field $(1.5 \mathrm{Vpp}, 1 \mathrm{MHz})$. The cells were then transported along 
the length of the electrode into the gap by exploiting an electric field induced flow at a lower voltage $(0.5 \mathrm{~V})$. The two electrodes tapered to a point small enough that a single bacterium would completely bridge the electrodes and detection could be achieved.

\subsubsection{Conductometric detection}

Direct measurement of the conductance between two electrodes with a nano-sized gap can be a highly sensitive technique for detecting bioparticles. A series of reports have been published by Suehiro et al. to detect dielectrophoretically trapped bacteria by measuring changes in conductance (1999; 2003a; 2003b; 2003c; 2005; 2006). The bacteria were collected within a small gap $(5 \mu \mathrm{m})$ between the microelectrode arrays by trapping the cells at the electrode edge with pDEP. After collection, an improved detection method was described by this group using electropermeabilization (Suehiro et al., 2003b; 2005). While cells can be destroyed using AC electric fields within a specific frequency window (Menachery \& Pethig, 2005), electropermeabilization causes the cell membrane to become permeable in order to increase the apparent conductivity of the trapped bacteria. Once applied, the bacterial cell wall leaks intracellular ions into the surrounding medium and transiently increases the conductance (Fig. 7). Using this method, the detection time of yeast cells and $E$. Coli cells was observed to shorten by two orders of magnitude to $15 \mathrm{~min}$ and $3 \mathrm{hr}$, respectively and the sensitivity was improved to $10^{2} \mathrm{CFU} / \mathrm{mL}$.

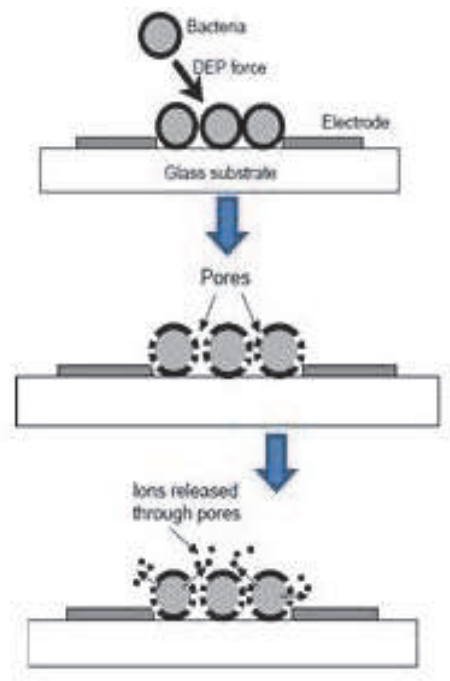

Fig. 7. A schematic diagram of electropermeabilization. The cells are first trapped, and then ruptured via an increased electric field followed by the subsequent release of intercellular ions to the surrounding area (Suehiro et al., 2003b). Reused with permission.

Selectivity for these detection methods was demonstrated by exploiting the different dielectric properties of cell mixtures. Selective detection of viable cells from a mixture of viable and non-viable cells was achieved using DEP collection at two different electric field frequencies. At $100 \mathrm{kHz}$ the viable and nonviable bacteria were trapped near an electrode corner due to positive DEP and their conductances changed proportionally with time. At 1 
$\mathrm{MHz}$ only viable bacterial cells were trapped by positive DEP as the conductance change over time was less remarkable (Suehiro et al., 2003c). The increase in conductance indicated that certain areas of the electrode gap had been bridged by trapped bacteria.

To enhance the detection of dielectrophoretically collected particles, metal nanoparticles have been used to transform nonconductive trapped particles into conductive interparticleconnected entities through metal deposition. For example, silver particles attached to DEP trapped bioparticles bridged the gap between two microelectrodes by silver nucleation (Velev \& Kaler, 1999). Latex particles coated with protein A were dielectrophoretically trapped between micron-sized gold electrodes and stabilized by a non-ionic surfactant. Adsorption of protein A onto the latex surface yielded a sensing interface for the specific association of the human immunoglobulin (IgG) antigen. The association of the human immunoglobulin on the surface was probed by the binding of secondary gold labelled antihuman IgG antibodies, followed by the catalytic deposition of a silver layer on the gold nanoparticles. The silver layer bridged the gap between the two microelectrodes, resulting in a resistance of 50-70 $\Omega$, whereas the negative control gave a resistance of $10^{3} \Omega$. The lower detection limit for this model sensor was calculated at $2 \times 10^{-13}-2 \times 10^{-14} \mathrm{M}$.

\subsubsection{Impedimetric detection}

Impedimetric detection is one of the most promising techniques for developing label-free, real time, and non-invasive methods for bioparticle detection. Milner et al. (1998) first proposed a differential impedance method for the quantitative detection of DEP captured bacteria and opened the door for biosensors where non-visible sub-micrometer bioparticles, such as viruses and DNA fragments, could be quantitatively investigated. This is not to suggest that impedimetric detection can only be used in isolation. In conjunction with optical monitoring, impedance has been used for the characterization of prohibitively small bioparticles (Guan et al., 2004).

Dielectrophoretic impedence measurement (DEPIM), a new method reported by Suehiro et al., occurs when there is an impedance change as interdigitated microelectrodes are connected due to the trapping and pearl-chain formation of cells by DEP (Suehiro et al., 1999). A 'pearl-chain' occurs during capture when bioparticles become dielectrophoretically attracted towards one another and form strings of particles resembling a chain of pearls. This pearl chain can enhance sensing by being electrically connected in parallel within the electrode gap, thus increasing the conductance and capacitance between the electrodes. The conductance, $G_{T}$ and capacitances, $C_{T}$ between the electrodes are found to increase proportionally with the increase in cell concentration. By fitting the measured $G_{T}$ and $C_{T}$ values, a linear calibration chart was derived that enables the absolute measurements of cell concentration. This method accurately assayed E. Coli cells suspended in solution at a concentration of $10^{5} \mathrm{CFU} / \mathrm{mL}$ within $10 \mathrm{~min}$. DEPIM has been used to concentrate bacterial cells (L. monocytogenes) from dilute solutions $\left(10^{5} \mathrm{cfu} / \mathrm{mL}\right)$ in order to detect the metabolic activity of the bacteria and provide enhanced sensitivity for the biosensor. (Sjöberg et al., 2005). After trapping the cell on the sensor surface, impedance sensing arose from the differences in the physical properties, i.e., differences in conductivity and permittivity, between the particles and the suspending medium as well as the changes in the geometric form of the collected particle on the electrode array. Other studies found that the changes in the permittivity of the dielectric between the electrodes are proportional to the total volume of the suspending medium replaced by the DEP collected particles (Allsopp et al., 1999). Thus, a linear relationship between the capacitance change and cell concentration was found. 
The DEPIM method was further developed with improved selectivity and sensitivity by applying electropermeabilization (Suehiro et al., 2003b), antibody-antigen interactions (Suehiro et al., 2003a; Suehiro et al., 2006; Suehiro et al., 2005) and different DEP forces (Suehiro et al., 2003c). In a series of publications, this group reported the detection of cells with high selectivity by using antigen-antibody reactions (Suehiro et al., 2006). This phenomenon was employed with DEPIM measurement via agglutination and immobilization and is illustrated in Fig. 8. An antibody specific to the target bacteria was added to the cell suspension to cause agglutination. pDEP was employed to attract particles to an electrode tip. At the electrode tips, the antibody was in a region of high concentration of the target bacteria, thereby increasing the amount of agglutination. After washing, a second round of DEP collection was used where the conditions of the DEP force and the drag forces were adjusted by varying the strength of the electric field so that only agglutinated products of the target bacteria were selectively trapped. A second method was proposed where immobilization for DEPIM relied on an electrode coated with immobilized antibodies prior to the experiment. The DEP force was then adjusted to be strong enough to bring bacteria to the chip surface, but not enough to overcome the drag force exerted by the flowing liquid. This allowed for simultaneously trapping the target bacteria by the antibody-antigen and suppressed non-specific bacteria binding.
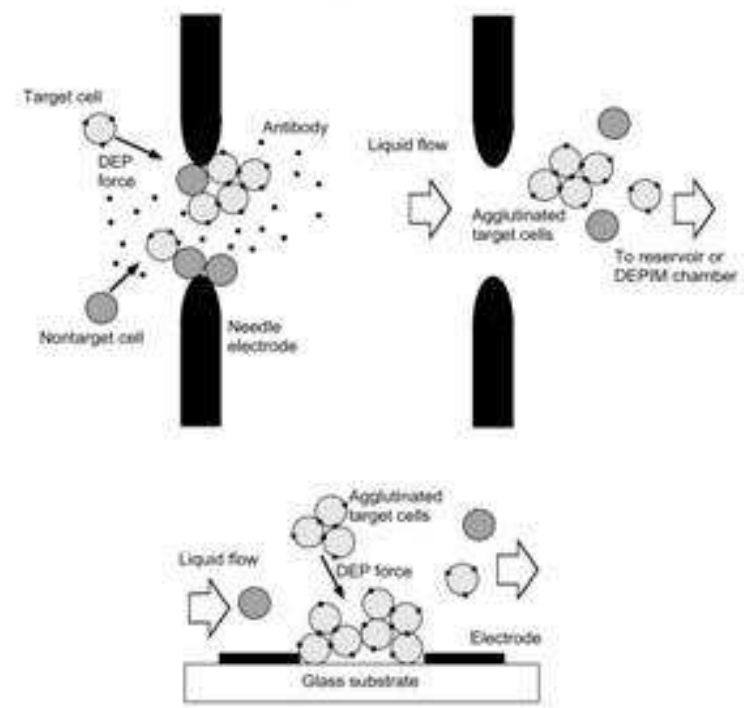

Fig. 8. A schematic diagram of DEPIM for agglutinated bacteria. The top schematic demonstrates trapping between electrode tips assisted with pDEP. The target bacteria become agglutinated at the tips and are then washed away to the reservoir. The agglomerates can then be collected more easily as shown in the bottom schematic (Suehiro $e t$ al., 2003a; 2003b). Reused with permission.

To miniaturize the analytical procedures for microorganism detection, a lab-on-a-chip device integrated with DEP based moving cages was demonstrated where the movement of the cages was achieved through actuation. Coupled with impedance based detection this 
lab-on-a-chip had no need for fluid flow or external optical components (Medoro et al., 2003). The cells are trapped in a stable levitation under the influence of an electric field and were then moved to a target location. The DEP cages were observed to shift and merge, consequently increasing the particle concentration within the cage. Impedance detection of E. Coli in tap water has also been achieved with the AC electroosmotic trapping of the bacteria using $1 \mathrm{~V}_{\mathrm{RMS}}$ at $100 \mathrm{~Hz}$ (Wu et al., 2005b). Detection was possible for E. Coli suspended in tap water at a concentration of $5 \times 10^{3} \mathrm{CFU} / \mathrm{ml}$ after trapping by $\mathrm{AC}$ electroosmosis. From the impedance results it was concluded that the system could detect pathogenic cells at a concentration of $10^{4} \mathrm{cell} / \mathrm{mL}$.

Single wall carbon nanotubes (SWCNTs) polarize in the presence of an electric field and can undergo self-assembled aggregation due to dipole-dipole interactions. Furthermore, they are good conductors and can change the conductance between the two microelectrodes by forming a bridge across the electrode gap, acting as a super capacitor. The strong dipoles of SWCNTs allow them to absorb onto the bioparticles and in a mixture of SWCNTs with bacteria, the impedimetric detection of bacteria was enhanced. Without CNT under the conditions applied, no bacteria were collected, however, with CNT enhanced DEP capture bacteria were collected and detected, as shown in Fig. 9 (Zhou et al., 2006). The authors suggested that the enhanced DEP trapping of bacteria was probably due to the stronger electric fields, and hence stronger DEP forces, generated near the dispersed SWCNTs. The transport time between the bioparticles and the sensor was shown to be greatly reduced and that the bacteria were concentrated and detected in less than $10 \mathrm{~min}$ at a concentration of $10^{4}$ particles $/ \mathrm{mL}$. Dielectrophoretic collection, impedence detection and characterization of DNA have also been reported by a number of researchers (Hölzel \& Bier, 2004; Linko et al., 2009).

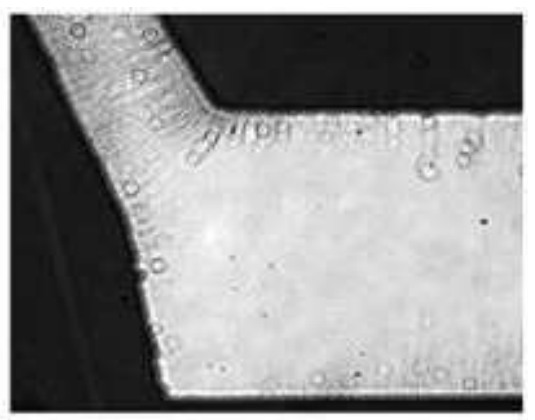

Fig. 9. CNT $(0.2 \mathrm{mg} / \mathrm{mL})$ enhanced collection of E. Coli bacteria $\left(10^{5} \mathrm{CFU} / \mathrm{mL}\right)$ (Zhou et al., 2006). Reused with permission.

\subsubsection{Coulometric detection}

In capacitance cytometry, a change in the total capacitance across a pair of microelectrodes is measured as the individual cell is allowed to pass through a microfluidic channel. As previously mentioned in section 3.3, DNA polarizes in an applied low frequency AC electric field. Capacitance measurement is employed by means of detecting and quantifying the polarization response of DNA as the cell passed through a $1 \mathrm{kHz}$ electric field. Capacitance detection of DNA in solution has been applied by measuring the capacitance change between the planar microelectrodes (Henning et al., 2008). Total DNA content of a cell has 
also been quantified by using capacitance cytometry, a termed coined by the authors to describe the linear relationship between the AC-capacitance and the DNA content (Sohn et al., 2000). A new method was recently published where the capacitive detection of viruses was achieved with an extremely low detection limit by using peptide nanotubes, a concept similar to the enhancement provided by CNT for bacteria that was discussed earlier (de la Rica et al., 2008). Self assembled peptide nanotubes coated with a virus specific antibody were trapped between a pair of electrodes by pDEP. Binding of the virus to the antibody caused a decrease in the permittivity as well as the capacitance between the electrodes due to the lower dielectric constant of the virus than that of the medium. Compared to other label free optical based transducers, this peptide nanotube based electrical transducer demonstrates a better detection limit for the herpes simplex virus type 2 with a detection limit of $10^{2} \mathrm{PFU} / \mathrm{mL}$ achieved within $1 \mathrm{hr}$.

\section{Conclusions}

The use of surface based biosensors with enhanced collection via AC electrokinetics allows for miniaturized, portable systems for the detection and characterization of potential pathogens. The research presented here has shown that the diffusion limitation bottleneck of traditional biosensors can be overcome with the aid of microelectrode arrays embedded on the sensor's surface. AC electrokinetic amplification for the enhanced bioparticle collection at virtually any location on a biosensor's surface can be achieved through positive or negative dielectrophoresis, AC electroosmosis or electrothermal flow, all of which provide a versatility of application for microelectromechnical devices. Furthermore, this technique is compatible with a range of detection methods including optical, mass and electrical based sensing. With the proliferation of micro- and nanotechnologies, and the need for onsite detection, a portable miniaturized system capable of detecting low concentrations of potentially dangerous pathogens is desirable. Commercially available lab-on-a-chip sensors capable of processing samples for the detection of multiple pathogenic compounds via an array of biosensors where the role of AC electrokinetics provides both sample amplification and transportation is quickly approaching reality.

\section{References}

Akin, D., Li, H., \& Bashir, R. (2004). Real-Time Virus Trapping and Fluorescent Imaging in Microfluidic_Devices. Nano Lett., Vol. 4, pp. (257-259)

Allsopp, D.W.E., Milner, K.R., Brown, A.P., \& Betts, W.B. (1999). Impedance technique for measuring dielectrophoretic collection of microbiological particles. J. Phys. D: Appl. Phys., Vol. 32, pp. (1066-1074)

Asbury, C.L., Diercks, A.H., \& Engh, G.V.D. (2002). Trapping of DNA by dielectrophoresis. Electrophoresis, Vol. 23, pp. (2658-2666)

Beck, J.D., Shang, L., Marcus, M.S., \& Hamers, R.J. (2005). Manipulation and Real-Time Electrical Detection of Individual Bacterial Cells at Electrode Junctions: A Model for Assembly of Nanoscale BiosystemsNano Lett., Vol. 5, pp. (777-781)

Becker, F.F., Wang, X-B., Huang, Y., Pethig, R., Vykoukal, J., \& Gascoyne, P. R. (1995). Separation of human breast cancer cells from blood by differential dielectric affinity. Proc. Natl. Acad. Sci. USA, Cell Biology, Vol. 92, pp. (860-864) 
Betts, W. B. (1995). The potential of dielectrophoresis for the real-time detection of microorganisms in foods. Trends in Food Sci. Technol., Vol. 6, pp. (51-58)

Bhatia, S.K., Shriver-Lake, L.C., Prior, K.J., Georger, J.H., Calvert, J.M., Bredehorst, R., \& Ligler, F.S. (1989). Use of Thiol-terminated silanes and heterobifunctional crosslinkers for immobilization of antibodies on silica surfaces. Anal. Biochem., Vol. 178, pp. (408-413)

Burt, J.P. H., Al-Ameen, T.A.K, \& Pethig, R. (1989). An optical dielectrophoresis spectrometer for low -frequency measurements on colloidal suspensions. J. Phys. E: Sci. Instrum., Vol. 22, pp. (952-957)

Castellanos, A., Ramos, A., Gonzalez, A., Green, N.G., \& Morgan, H. (2003). Electrohydrodynamics and dielectrophoresis in Microsystems: scaling laws. J. Phys. D: Appl. Phys., Vol. 36, pp. (2584-2597)

Cheng, J., Sheldon, E.L., Wu, L., Uribe, A., Gerrue, L.O., Carrino, J., Heller, M.J., \& O'Connell, J.P. (1998a). Preparation and hybridization analysis of DNA/RNA from E. coli on microfabricated bioelectronic chips. Nature Biotechnology, Vol. 16, pp. (541-546)

Cheng, J., Sheldon, E.L., Wu, L., Heller, M.J., \& O'Connell, J.P. (1998b). Isolation of Cultured Cervical Carcinoma Cells Mixed with Peripheral Blood Cells on a Bioelectronic Chip. Anal. Chem., Vol. 70, pp. (2321-2326)

Cheng, I-F., Chang, H-C., Hou, D., \& Chang, H-C. (2007). An integrated dielectrophoretic chip for continuous bioparticle filtering, focusing, sorting, trapping, and detecting. Biomicrofluidics, Vol. 1, pp. (021503:1-15)

Chou, C-F., Tegenfeldt, J. O., Bakajin, O., Chan, S. S., Cox, E. C., Darnton, N., Duke, T. \& Austin, R. H. (2002). Electrodeless Dielectrophoresis of Single- and DoubleStranded DNA. Biophysical Journal, Vol. 83, pp. (2170-2179)

Costanzo, P. J., Liang, E., Patten, T. E., Collins, S. D., \& Smith., R. L. (2005). Biomolecule detection via target mediated nanoparticle aggregation and dielectrophoretic impedance measurement. Lab Chip, Vol. 5, pp. (606-610)

Cui, L., Zhang, T., \& Morgan, H. (2002). Optical particle detection integrated in a dielectrophoretic lab-on-a-chip. J. Micromech. Microeng., Vol. 12, pp. (7-12)

Dewarrat, F., Calame, M., \& Schönenberger, C. (2002). Orientation and Positioning of DNA Molecules with an Electric Field Technique. Single Mol., Vol. 3, pp. (189-193)

Dimitrov, D.S., \& Zhelev, D.V. (1987). Dielectrophoresis of individual Cells: experimental Methods and results, Bioelectrochemistry and Bioenergetics, Vol. 17, pp. (549-557)

Docoslis, A., Espinoza, L.A.T., Zhang, B., Cheng, L-L., Israel, B.A., Alexandridis, P., \& Abbott, N.L. (2007) Using Nonuniform Electric Fields To Accelerate the Transport of Viruses to Surfaces from Media of Physiological Ionic Strength. Langmuir, Vol. 23, , pp. (3840-3848)

Fatoyinbo, H.O., Hoettges, K.F., Reddy, S.M., \& Hughes, M.P. (2007). An integrated dielectrophoretic quartz crystal microbalance (DEP-QCM) device for rapid biosensing applications. Biosensors and Bioelectronics, Vol. 23, pp. (225-232)

Feng, J.J., Krishnamoorthy, S., \& Sundaram, S. (2007). Numerical analysis of mixing by electrothermal induced flow in microfluidic systems. Biomicrofluidics, Vol. 1, pp. (024102:1-8)

Frenea, M., Faure, S.P., Le Pioufle, B., Coquet, Ph., \& Fujita, H. (2003). Positioning living cells on a high-density electrode array by negative dielectrophoresis. Materials Science and Engineering C, Vol. 23, pp. (597-603) 
Gagnon, Z., \& Chang, H-C. (2005). Aligning Fast Alternating Current Electroosmotic Flow Fields and Characteristic Frequencies with dielectrophoretic Traps to Achieve Rapid Bacteria detection. Electrophoresis, Vol. 26, pp. (3725-3737)

Gagnon, Z., Senapati, S., Gordon, J., \& Chang, H-C. (2008). Dielectrophoretic detection and quantification of hybridized DNA molecules on nano-genetic particles. Electrophoresis, Vol. 29, pp. (4808-4812)

Gascoyne, P.R.C., Huang, Y., Pethig, R., Vykoukal, J., \& Becker, F. F. (1992). Dielectrophoretic separation of mammalian cells studied by computerized image analysis. Meas. Sci. Technol., Vol. 3, pp. (439-445)

Gascoyne, P., Satayavivad, J., \& Ruchirawat, M. (2004). Microfluidic approaches to malaria detection. Acta Tropica, Vol. 89, pp. (357-369)

Green, N.G., \& Morgan, H. (1997). Dielectrophoretic investigations of sub-micrometre latex spheres. J. Phys. D: Appl. Phys., Vol. 30, pp. (2626-2633)

Green, N.G., \& Morgan, H. (1998). Separation of submicrometre particles using a combination of dielectrophoretic and electrohydrodynamic forces. J. Phys. D: Appl. Phys., Vol. 31, pp. (L25-L30)

Green, N.G., Ramos, A., Gonzalez, A., Morgan, H., \& Castellanos, A. (2002). Fluid flow induced by nonuniform ac electric fields in electrolytes on microelectrodes. III. Observation of streamlines and numerical simulation. Physical Review E, Vol. 66, pp. (026305:1-11)

Grom, F., Kentsch, J., Müller, T., Schnelle, T., \& Stelzle, M. (2006). Accumulation and trapping of hepatitis A virus particles by electrohydrodynamic flow and dielectrophoresis. Electrophoresis, Vol. 27, pp. (1386-1393)

Guan, J.G., Miao, Y.Q., \& Zhang, Q.J. (2004). Impedimetric Biosensors. Biosci. Bioeng., Vol. 97, pp. (219-226)

Hamblin, M.N., Xuan, J., Maynes, D., Tolley, H. D., Belnap, D. M., Woolley, A. T., Leeb, M. L., \& Hawkins, A. R. (2010). Selective trapping and concentration of nanoparticles and viruses in dual-height nanofluidic channels. Lab Chip, Vol. 10, pp. (173-178)

Henning, A., Henkel, J., Bier, F.F., \& Hölzel, R. (2008). Label-free electrical quantification of the dielectrophoretic response of DNA. PMC Biophysics Vol. 1, No. 4

Hoettges, K.F., McDonnell, M.B., \& Hughes, M.P. (2003). Use of combined dielectrophoretic/electrohydrodynamic forces for biosensor enhancement. J. Phys. D: Appl. Phys., Vol. 36, pp. (L101-L104)

Hölzel, R., \& Bier, F.F. (2003). Dielectrophoretic manipulation of DNA. IEE ProcNanobiotechnol., Vol. 150, pp. (47-53)

Hölzel, R., \& Bier, F.F. (2004). Monitoring Dielectrophoretic Collection of DNA by Impedance Measurement. AIP Conference Proceedings, Vol. 725, pp. (77-83)

Hou, D., Maheshwari, S., \& Chang, H.C. (2007). Rapid bioparticle concentration and detection by combining a discharge driven vortex with surface enhanced Raman scattering. Biomicrofluidics, Vol. 1, pp. (014106:1-13)

Huang, Y., \& Pethlg, R. (1991). Electrode design for negative dielectrophoresis. Meas. Sci. Technol., Vol. 2, pp. (1142-1146)

Hübner, Y., Hoettges, K.F., McDonnell, M.B., Carter, M.J., \& Hughes, M.P. (2007). Applications of dielectrophoretic/electro-hydrodynamic "zipper" electrodes for detection of biological nanoparticles. Int J Nanomedicine., Vol. 2, No. 3, pp. (427-431)

Hughes, M. P., Morgan, H., Rixon, F. J., Burt, J. P. H., \& Pethig, R. (1998). Manipulation of herpes simplex virus type 1 by dielectrophoresis, Biochim. Biophys. Acta., Vol. 1425, pp. (119-126) 
Hughes, M. P., Morgan, H., \& Rixon, F. J. (2001). Dielectrophoretic manipulation and characterization of herpes simplex virus-1 capsids. Eur. Biophys. J., Vol. 30, pp. (268272)

Humberto, F., Morales, F., Duarte, J. E., \& Martí, J. S. (2008). Non-uniform electric fieldinduced yeast cell electrokinetic behavior. Revista Ingenieria E Investigacion, Vol. 28, pp. (116-121)

Islam, N., Lian, M., W \& u, J. (2007). Enhancing microcantilever capability with integrated AC electroosmotic trapping. Microfluid. Nanofluid., Vol. 3, pp. (369-375)

Jen, C-P., \& Chen, T-W. (2009). Selective trapping of live and dead mammalian cells using insulator-based dielectrophoresis within open-top microstructures. Biomed. Microdevices, Vol. 11, pp. (597-607)

Kawabata, T., \& Washizu, M. (2001). Dielectrophoretic Detection of Molecular Bindings. IEEE Transactions on Industry Applications, Vol. 37, pp. (1625-1633)

Koo, O.K., Liu, Y., Shuaib, S., Bhattacharya, S., Ladisch, M.R., Bashir, R., \& Bhunia, A.K. (2009). Targeted Capture of Pathogenic Bacteria Using a Mammalian Cell Receptor Coupled with dielectrophoresis on a Biochip. Anal. Chem., Vol. 81, pp. (3094-3101)

Kurosawa, O., Okabe, K., \& Washizu, M. (2000). DNA analysis based on physical manipulation. Proceedings of 13th Micro Electro Mechanical Systems., pp. (311-316)

Lagally, E.T., Lee, S-H., \& Soh, H.T. (2005). Integrated microsystem for dielectrophoretic cell concentration and genetic Detection. Lab Chip, Vol. 5, pp. (1053-1058)

Lapizco-Encinas, B. H., \& Palomares, M. R. (2007). Dielectrophoresis for the manipulation of Nanobioparticles. Electrophoresis, Vol. 28, pp. (4521-4538)

Li, H., \& Bashir, R. (2002). Dielectrophoretic separation and manipulation of live and heattreated cells of Listeria on microfabricated devices with interdigitated electrodes. Sensors and Actuators B: Chemical, Vol. 86, pp. (215-221)

Li, D. (2004). Electrokinetics in microfluidics, Elsevier

Linko, V., Paasonen, S-T., Kuzyk, A., Torma, P., \& Toppari, J.J. (2009). Characterization of the Conductance Mechanisms of DNA Origami by AC Impedance Spectroscopy. Small, Vol. 5, pp. (2382-2386)

Livache, T., Bazin, H., Caillat, P., \& Roget., A. (1998). Electroconducting polymers for the construction of DNA or peptide arrays on silicon chips. Biosensors $\mathcal{E}$ Bioelectronics, Vol. 13, pp. (629-634)

Markx, G.H., Huang, Y., Zhou, X-F., \& Pethig, R. (1994). Dielectrophoretic characterization and separation of micro-organisms. Microbiology, Vol. 140, pp. (585-591)

Markx, G.H., \& Pethig, R. (1995). Dielectrophoretic Separation of Cells: Continuous Separation. Biotechnology and Bioengineering, Vol. 45, pp. (337-343)

Medoro, G., Manaresi, N., Leonardi, A., Altomare, L., Tartagni, M., \& Guerrieri, R. (2003). A Lab-on-a-Chip for Cell Detection and Manipulation. IEEE Sensors Journal, Vol. 3, No. 3, pp. (317-325)

Menachery, A., \& Pethig, R. (2005). Controlling cell destruction using dielectrophoretic Forces. IEE Proc. Nanobiotechnol., Vol. 152, pp. (145-149).

Milner, K.R., Brown, A.P., Allsopp, D.W.E., \& Betts, W.B. (1998). Dielectrophoretic classification of bacteria using differential impedance measurements. Electronics Letters, Vol. 3, pp. (66-68)

Morgan, H., \& Green, N.G. (1997). Dielectrophoretic manipulation of rod-shaped viral particles. Journal of Electrostatics, Vol. 42, pp. (279-293)

Morgan, H. \& Green, N.G. (2003). AC electrokinetics: colloids and nanoparticles, Research Studies Press Ltd. 
Müller, T., Fiedler, S., Schnelle, T., Ludwig, K., Junga, H., \& Fuhr, G. (1996). High frequency electric fields for Trapping viruses. Biotechnology Techniques, Vol. 10 pp. (221-226)

Mullery, T., Gerardinoz, A., Schnelley, T., Shirleyy, S. G., Bordoniz, F., Gasperisz, G. D., Leonix, R., \& Fuhr, G. (1996). Trapping of micrometre and sub-micrometre particles by high-frequency electric fields and hydrodynamic forces. J. Phys. D: Appl. Phys., Vol. 29, pp. (340-349)

Oblak, J., Krizaj, D., Amon, S., Macek-Lebar, A., \& Miklavcic, D. (2007). Separation of electroporated and non-electroporated cells by means of dielectrophoresis. IFMBE Proceedings, Vol. 16, pp. (178-181)

Pandey, S., \& White, M.H. (2004). Detection of Dielectrophoretic Driven Passage of Single Cells through Micro-Apertures in a Silicon Nitride Membrane. Conf. Proc. IEEE Eng. Med. Biol. Soc., Vol. 3, pp. (1956-1959)

Park, I-S., \& Kim, N. (1998). Thiolated Salmonella antibody immobilization onto the gold surface of piezoelectric quartz crystal. Biosensors E Bioelectronics, Vol. 13, pp. (10911097)

Park, K., Akin, D., \& Bashir, R. (2007). Electrical capture and lysis of vaccinia virus particles using silicon nano-scale probe array. Biomed. Microdevices, Vol. 9, pp. (877-883)

Park, K., Jang, J., Irmia, D., Sturgis, J., Lee, J., Robinson, P., Tonerd, M., \& Bashir, R. (2008). 'Living cantilever arrays' for characterization of mass of single live cells in fluids. Lab on a Chip, Vol. 8, pp. (1034-1041)

Pethig, R. (1996). Dielectrophoresis: Using In homogeneous AC Electrical Fields to Separate and Manipulate Cells. Crirical Reviews in Biotechnology, Vol. 16, pp. (331-348)

Pethig, R., \& Markx, G.H. (1997). Applications of dielectrophoresis in biotechnology. Trends Biotechnol., Vol. 15, pp. (426-432)

Pethig, R., Huang, Y., Wang, X-B., \& Burt, J.P. H. (1992). Positive and negative dielectrophoretic collection of colloidal particles using interdigitated castellated microelectrodes. J. Phys. D: Appl. Phys., Vol. 24, pp. (881-888)

Pohl, H. A. (1951). The motion and precipitation of suspensoids in divergent electric fields. Journal of Applied Physics, Vol. 22, pp. (869-871)

Pohl, H.A., \& Pethig, R. (1977). Dielectric measurements using non-uniform electric field (dielectrophoretic) effects. J. Phys. E: Sci. Instrum., Vol. 10, pp. (190-193)

Price, J.A.R., Burt, J. P.H., \& Pethig, R. (1988). Applications of a new optical technique for measuring the dielectrophoretic behaviour of micro-organisms. Biochim. Biophys. Acta, Vol. 964, pp. (221-230)

Radke, S.M., \& Alocilja, E.C. (2005). A microfabricated biosensor for detecting foodborne bioterrorism agents. IEEE Sensors Journal, Vol. 5, pp. (744-750)

Ramos, A., Morgan, H., Green, N.G., \& Castellanos, A. (1998). Ac electrokinetics: a review of forces in microelectrode structures. J. Phys. D: Appl. Phys., Vol. 31, pp. (2338-2353)

Ramos, A., Morgan, H., Green, N.G., \& Castellanos, A. (1999). AC Electric-Field-Induced Fluid Flow in Microelectrodes. J.Coll. Int. Sci., Vol. 217, pp. (420-422)

de la Rica, R., Mendoza, E., Lechuga, L.M., \& Matsui, H. (2008). Label-Free Pathogen Detection with Sensor Chips Assembled from Peptide Nanotubes. Angew. Chem. Int. Ed., Vol. 47, pp. (9752-9755)

Sauli, U.S., Panayiotou, M., Schnydrig, S., Jordan, M., \& Renaud, P. (2005). Temperature measurements in microfluidic systems: Heat dissipation of negative dielectrophoresis barriers. Electrophoresis, Vol. 26, pp. (2239-2246) 
Schnelle, T., Müller, T., Fiedler, S., Shirley, S. G., Ludwig, K., Herrmann, A., Fuhr, G., Wagner B., \& Zimmermann, U. (1996). Trapping of viruses in high-frequency electric field cages. Naturwisswnschaften, Vol. 83, pp. (172-176)

Sigurdson, M., Wang, D., \& Meinhart, C.D. (2005). Electrothermal stirring for heterogeneous immunoassays. Lab Chip, Vol. 5, pp. (1366-1373)

Sjöberg, R. G., Morisette, D. T., \& Bashir, R. (2005). Impedance Microbiology-on-a-Chip: Microfluidic Bioprocessor for Rapid Detection of Bacterial Metabolism. J. Microelectromech. Syst., Vol. 14, pp. (829-838)

Sohn, L.L., Saleh, O.A., Facer, G.R., Beavis, A.J., Allan, R.S., \& Notterman, D.A. (2000). Capacitance cytometry: Measuring biological cells one by one. Proc Natl Acad Sci, Vol. 97, pp. (10687-10690)

Suehiro, J., Yatsunami, R., Hamada, R., \& Hara, M. (1999) Quantitative estimation of biological cell concentration suspended in aqueous medium by using dielectrophoretic impedance measurement method. J. Phys. D: Appl. Phys., Vol. 32, pp. (2814-2820)

Suehiro, J., Noutomi, D., Shutou, M., \& Hara, M. (2003a). Selective detection of specific bacteria using dielectrophoretic impedance measurement method combined with an antigen-antibody reaction. Journal of Electrostatics, Vol. 58, pp. (229-246)

Suehiro, J., Shutou, M., Hatano, T., \& Hara, M. (2003b). High sensitive detection of biological cells using dielectrophoretic impedance measurement method combined with electropermeabilization, Sensors and Actuators B, Vol. 96, pp. (144-151)

Suehiro, J., Hamada, R., Noutomi, D., Shutou, M., \& Hara, M. (2003c). Selective detection of viable bacteria using dielectrophoretic impedance measurement method. Journal of Electrostatics, Vol. 57, pp. (157-168)

Suehiro, J., Hatano, T., Shutou, M., H \& ara, M. (2005). Improvement of electric pulse shape for electropermeabilization assisted dielectrophoretic impedance measurement for high sensitive bacteria detection. Sensors and Actuators B, Vol. 109, pp. (209-215)

Suehiro, J., Ohtsubo, A., Hatano, T., \& Hara, M. (2006). Selective detection of bacteria by a dielectrophoretic impedance measurement method using an antibody-immobilized electrode chip. Sensors and Actuators B, Vol. 119, pp. (319-326)

Sungmoon, H., Woonam, Y., Park, J. C., \& Jung., H. Y. (2009). Dielectrophoretic Separation of Airborne Microbes and Dust Particles Using a Microfluidic Channel for RealTime Bioaerosol Monitoring. Environ. Sci. Technol., Vol. 43, pp. (5857-5863)

Talary, M.S., \& Pethig, R. (1994). Optical technique for measuring the positive and negative dielectrophoretic behaviour of cells and colloidal suspensions. IEE Proc. Sci. Meas. Technol., Vol. 141, pp. (395-399)

Talary, M.S., Burt, J.P.H., Tame, J.A., \& Pethig, R. (1996). Electromanipulation and separation of cells using travelling electric fields. J. Phys. D: Appl. Phys., Vol. 29, pp. (2198-2203)

Tomkins, M.R., Wood, J.A., \& Docoslis, A. (2008). Observations and Analysis of Electrokinetically Driven Particle Trapping in Planar Microelectrode Arrays. The Canadian Journal of Chemical Engineering, Vol. 86, pp. (609-621)

Tomkins, M.T., Chow, J., Lai, Y-J., Docoslis, A., (submitted, 2011) A coupled cantilevermicroelectrode biosensor for enhanced pathogen detection.

Tuukkanen, S., Toppari, J. J.,Kuzyk, A. Hirviniemi, L., Hytönen, V.P. Ihalainen, T. \& Törmä, P. (2006). Carbon Nanotubes as Electrodes for Dielectrophoresis of DNA. Nano Lett., Vol. 6, pp. (1339-1343) 
Velev, O.D., \& Kaler, E.W. (1999). In Situ Assembly of Colloidal Particles into Miniaturized Biosensors, Langmuir, Vol. 15, pp. (3693-3698)

Velusamy, V., Arshak, K., Korostynska, O., Oliwa, K., \& Adley, C. (2010). An overview of foodborne pathogen detection: In the perspective of biosensors. Biotechnology Advances, Vol. 28, pp. (232-254) 0734-9750

Walti, C. W*, Germishuizen, W. A., Tosch, P., Kaminski, C. F., \& Davies, A. G. (2007). AC electrokinetic manipulation of DNA. J. Phys. D: Appl. Phys., Vol. 40, pp. (114-118)

Wana, Y., Zhanga, D., \& Hou, B. (2009). Monitoring microbial populations of sulfatereducing bacteria using an impedimetric immunosensor based on agglutination assay. Talanta, Vol. 80, pp. (218-223)

Wang, T-H., Peng, Y., Zhang, C., Wong, P. K., \& Ho, C-M. (2005). Single-Molecule Tracing on a Fluidic Microchip for Quantitative Detection of Low-Abundance Nucleic Acids. J Am Chem Soc., Vol. 127, pp. (5354-2365)

Washizu, M., \& Kurosawa, O. (1990). Electrostatic Manipulation of DNA in Microfabricated Structures. IEEE Transactions on Industry Applications, Vol. 26, pp. (1165-1172)

Washizu, M., Kurosawa, O., Arai, I., Suzuki, S., \& Shimamoto, N. (1995). Applications of electrostatic stretch and-positioning of DNA IEEE Trans. Ind. Appl., Vol. 31, No. 3, pp. (447-456)

Washizu, M., Kimura, Y., Kobayashi, T., Kurosawa, O., Matsumoto, S., \& Mamine, T. (2004). Stretching DNA as a template for molecular construction. AIP Conference Proceedings Series, Vol. 725, pp. (67-77)

Washizu., M. (2005). Biological applications of electrostatic surface field effects. Journal of Electrostatics, Vol. 63, pp. (795-802)

Wong, P.K., Chen, C.Y., Wang, T.H., \& Ho, C.M. (2004b). Electrokinetic bioprocessor for concentrating cells and molecules. Anal. Chem., Vol. 76, pp. (6908-6914)

Wood, J. A., Zhang, B., Tomkins, M. R., \& Docoslis, A. (2007). Numerical investigation of AC electrokinetic virus trapping inside high ionic strength media. Microfluid Nanofluid, Vol. 3, pp. (547-560)

Wu, J., Ben, Y., Battigelli, D., \& Chang, H-C. (2005a). Long-Range AC Electroosmotic Trapping and Detection of Bioparticles. Ind. Eng. Chem. Res., Vol. 44, pp. (2815-2822)

Wu, J., Ben, Y., \& Chang, H.C. (2005b). Particle detection by electrical impedance spectroscopy with asymmetric-polarization AC electroosmotic trapping. Microfluid Nanofluid, Vol. 1, pp. (161-167)

Yamamoto, T., Kurosawa, O., Kabata, H., Shimamoto, N., \& Washizu, M. (2000). Molecular Surgery of DNA Based on Electrostatic Micromanipulation. IEEE Transactions on Industry Applications, Vol. 36, pp. (1010-1017)

Yang, L. (2009). Dielectrophoresis assisted immuno-capture and detection of foodborne pathogenic bacteria in biochips. Talanta, Vol. 80, pp. (551-558)

Yang, L., Banada, P.P., Bhunia, A.K., \& Bashir, R. (2008). Effects of Dielectrophoresis on Growth, Viability and Immuno-reactivity of Listeria monocytogenes. J Biol Eng Vol. 2, No. 1, Record (6)

Yang, L., Banada, P.P., Chatni, M.R., Lim, K.S., Bhunia, A.K., Ladischde, M., \& Bashir, R. (2006). A multifunctional micro-fluidic system for dielectrophoretic concentration coupled with immuno-capture of low numbers of Listeria monocytogenes. Lab Chip, Vol. 6, pp. (896-905)

Zhou, R., Wang, P., \& Chang, H-C. (2006). Bacteria Capture, concentration and detection by alternating current dielectrophoresis and self-assembly of dispersed single-wall carbon nanotubes. Electrophoresis, Vol. 27, pp. (1376-1385) 


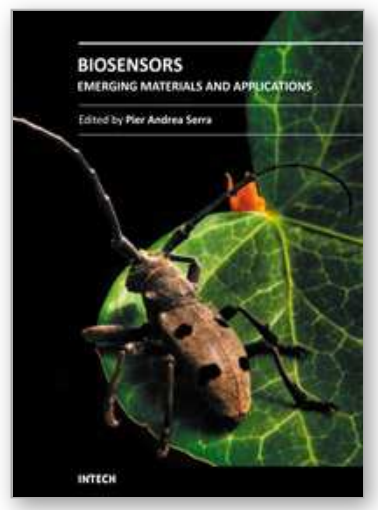

\author{
Biosensors - Emerging Materials and Applications \\ Edited by Prof. Pier Andrea Serra
}

ISBN 978-953-307-328-6

Hard cover, 630 pages

Publisher InTech

Published online 18, July, 2011

Published in print edition July, 2011

\begin{abstract}
A biosensor is a detecting device that combines a transducer with a biologically sensitive and selective component. Biosensors can measure compounds present in the environment, chemical processes, food and human body at low cost if compared with traditional analytical techniques. This book covers a wide range of aspects and issues related to biosensor technology, bringing together researchers from 19 different countries. The book consists of 27 chapters written by 106 authors and divided in three sections: Biosensors Technology and Materials, Biosensors for Health and Biosensors for Environment and Biosecurity.
\end{abstract}

\title{
How to reference
}

In order to correctly reference this scholarly work, feel free to copy and paste the following:

Protiva Rani Roy, Matthew Tomkins and Aristides Docoslis (2011). Enhancing the Performance of Surfacebased Biosensors by AC Electrokinetic Effects - a Review, Biosensors - Emerging Materials and Applications, Prof. Pier Andrea Serra (Ed.), ISBN: 978-953-307-328-6, InTech, Available from:

http://www.intechopen.com/books/biosensors-emerging-materials-and-applications/enhancing-theperformance-of-surface-based-biosensors-by-ac-electrokinetic-effects-a-review

\section{INTECH}

open science | open minds

\section{InTech Europe}

University Campus STeP Ri Slavka Krautzeka 83/A 51000 Rijeka, Croatia Phone: +385 (51) 770447 Fax: +385 (51) 686166 www.intechopen.com

\section{InTech China}

Unit 405, Office Block, Hotel Equatorial Shanghai No.65, Yan An Road (West), Shanghai, 200040, China 中国上海市延安西路65号上海国际贵都大饭店办公楼405单元 Phone: +86-21-62489820

Fax: +86-21-62489821 
(C) 2011 The Author(s). Licensee IntechOpen. This chapter is distributed under the terms of the Creative Commons Attribution-NonCommercialShareAlike-3.0 License, which permits use, distribution and reproduction for non-commercial purposes, provided the original is properly cited and derivative works building on this content are distributed under the same license. 